\title{
Improving student motivation for learning the second foreign language
}

\author{
Olga G. Selivanova - Chulpan R. Gromova - Nikolay A. Mashkin
}

DOI: 10.18355/XL.2018.11.01.18

\begin{abstract}
Second foreign language has been recently introduced into the curriculum of Russian schools. However, the language programs are not scientifically based and tested. Teaching and learning aids are not developed, either teaching techniques. This becomes the theme of the research discussed in the paper. The purpose of this paper is to justify and characterize the scientific and methodological approach to the process of improving motivation for learning the second foreign language on the basis of analysis of educational theory and practice. The paper presents a scientific and methodological approach to the development of schoolchildren motivation for second foreign language learning; motivation levels of schoolchildren for learning the second foreign language are described; organizational and pedagogical conditions necessary to improve schoolchildren motivation for second foreign language learning have been identified (the teacher should know the students' first foreign language (English) proficiency level; analyze quantitative and qualitative characteristics of their motivation to learn German as the second foreign language; take into account students' individual cognitive characteristics and educational requirements in learning the second foreign language; the teacher should be aware of the fact that it necessary to increase motivation of each student regardless of their language proficiency level); a system of assignments to organize individual and group work of students to improve their motivation for second foreign language learning has been developed and tested. The significance of the research consists in proving the effectiveness of the developed scientific methodological approach to developing schoolchildren motivation for learning the second foreign language. The paper is of practical value for second foreign language teachers, as they can use the data as the basis for developing a system of assignments aimed at increasing their students' motivation.
\end{abstract}

Key words: motivation development, second foreign language, communicative approach

\section{Introduction}

Russia's active participation in the Bologna process implies broad international cooperation in the field of education. If we take into account the fact that there are about 1.5 billion English speakers in the world, 700 million of those speaking Spanish, 130 million people speaking French, and about 100 million speaking German, we understand that language competence, i.e., knowledge of one, two or more languages, makes young people entering adult life more competitive in our information society. A high level of foreign language proficiency gives young people an opportunity to study at foreign universities, read books in the original language, get acquainted with other peoples' culture, and communicate both in virtual space and in live face-to-face interaction.

While learning two foreign languages at school is standard practice for most European schools, in Russia introduction of one more foreign language and the necessity to improve student motivation for learning this language is complex management and educational task for the whole system of education.

The necessity to explore the problems of teaching Second Foreign Language in Russian schools is determined by the state standards. In particular, Order No. 1577 of the Ministry of Education and Science of RF of December 31, 2015 "On Amendments to the Federal State Educational Standard of Basic General Education, approved by 
Order of the Ministry of Education and Science of the Russian Federation of December 17, 2010 No. 1897" (Order, 2010) states that Philology is a compulsory subject area in the Curriculum Plan, which also includes Second Foreign Language (paragraph 18.3.1). It is expected that all Russian schoolchildren will have been involved in the process of studying the second foreign language by 2020. In the longer term, in 2022, all students are to take the Unified State Exam in Foreign Language as a compulsory one along with Russian Language and Mathematics.

At the same time, the analysis of the Kirov region education system has shown that only 97 educational institutions offer two or more foreign languages, which is $20.86 \%$ of the total number of schools in the region. There are only 14 schools where students study two foreign languages, which is $3 \%$ of the total. There are 1,074 Foreign Language teachers (845 teachers of English, 268 teachers of German, 25 teachers of French, 2 teachers of Spanish, 1 teacher of Arabic, 1 teacher of Latin), and only 68 of them teach two or more foreign languages.

Such Kirov schools as the Vyatka Gymnasium of Humanities, Kirov Linguistic Gymnasium, Kirovo-Chepetsk Gymnasium No. 1, school No. 47 with advanced learning in some subjects and a few others have some experience in teaching Second Foreign Language. However, one feels a real need to develop scientifically-based approaches to second foreign language teaching.

The analysis of the educational process has shown that before students start to study Second Foreign Language and at the very beginning of this process, they are, as a rule, highly motivated. They want to speak to their peers in a foreign language; they find it attractive to recite poems and sing songs in a foreign language, to read and learn about other countries. Many see studying a foreign language as something "adventurous," they penetrate into a new, unfamiliar world; an opportunity to undergo a kind of a transformation seems exciting to them: "I am a native speaker," "I am a foreign language speaker." Most students are eager to have a good command of a foreign language, be able to communicate face-to-face, through a book and correspondence but when they start learning a foreign language, their attitude changes, many of them get disappointed. This process of learning a foreign language involves a period of accumulation of "building bricks," an inevitable stage of using a primitive content and overcoming various difficulties, which delays achievement of the goals they dream about (Gotlib, 2009).

The urgency of the research problem is also supported by the fact that in the process of learning the second foreign language, schoolchildren do not only get less motivated but also "anti motives" (Yurchenkova, 2010) appear - psychological, cognitive, and didactic barriers.

Considering motivation as the most important force in the process of mastering a foreign language, which ensures its effectiveness, it should be borne in mind that motivation is a part of the personal universe of a student and it is determined by his own ambitions, preferences, and requirements. The teacher's role is to indirectly influence it, to create conditions and form the basis thanks to which students become personally motivated in learning (Vartanov, 2003).

It is only recently that some research of international standing in the field of motivation for second foreign language learning has appeared in Russia (Vedishenkova, Gulyaeva, 2016). Therefore, the problem of developing a sustainable motivation of Russian schoolchildren for learning the second foreign language is an urgent scientific and pedagogical issue.

The purpose of this paper is to justify and describe the scientific and methodological approach to the development of motivation for second foreign language learning, based on the analysis of educational theory and practice. The main tasks set were the following:

XLinguae, Volume 11 Issue 1, January 2018, ISSN 1337-8384, eISSN 2453-711X 
- to identify the levels of schoolchildren motivation for learning the second foreign language and to describe their content;

- to work out and test a system of assignments for students studying the second foreign language, aimed at increasing their motivation;

- to determine organizational and pedagogical conditions for the development of schoolchildren motivation for second foreign language learning;

- to test the efficacy of the developed scientific and methodological approach.

\section{Literature Review}

Motivation is one of the fundamental problems of psychology both in Russia (Zimnyaya, 2014) and abroad (Ausuble, 1963, 1968; Ausuble, Robinson, 1969). A lot of attention is given to the issue of increasing motivation, maintaining and developing students' interest in Foreign Language both in methodology and in the psychology of teaching the subject. Educators emphasize its complex and multifaceted character and, in accordance with this, offer different approaches to handling the problem.

Researchers analyze the structure of motivation for foreign language learning taking into account the socio-cultural situation in which a modern schoolchild grows up. M.I. Dubrovin (2012) divides motivation into external and internal types. He regards general social motivation and motivation associated with the long-term development of an individual to be the external type, and communication motivation and motivation generated primarily by the educational activity itself (operational) to be the internal type. N.D. Galskova (2014) distinguishes five types of motivation for foreign language learning: target motivation - what is required to do the activity, what it is aimed at and the means used to carry it out - all these things are mastered easily; success motivation - if a student succeeds in learning a subject, then the subject is learned enthusiastically not only in the classroom, but students also participate in extracurricular activities; cross-cultural motivation - language reacts quickly to all changes in the life of a country, therefore reflecting its customs and traditions; aesthetic motivation helps to turn language learning into pleasure; instrumental motivation takes into account the personality of each student and offers them the possibility to fulfill themselves in their favourite kind of activity. All motivation types, according to the author, are of great value as they help a student to understand the sociocultural nature of the language.

Domestic researchers explain the increased motivation for learning a foreign language (including the second foreign language) by updated goals (Passov, Kuzovlev, Korostelev, 2010), which should be not only didactic but also philosophical in nature. P.V. Sysoeva (2011) considers a foreign language to be the main tool for a student to get acquainted with the culture of the postindustrial society. V.V. Safonova (2012) is of a similar opinion stating that globalization processes taking place in the modern world are directly related to cultural and linguistic expansion, involving schoolchildren as well. Their participation in intercultural interaction is a strong motivator for learning foreign languages.

Educators are actively developing ways of increasing motivation for foreign language learning taking into consideration cognitive needs of schoolchildren and trying to meet their current educational needs (Rogova, Nikitenko, 2009).

M.N. Mushkina (2017) and A.A. Cherkasova (2017), practicing teachers, lay emphasis on the following problems in second foreign language teaching: insufficient number of classroom hours, competing with the first foreign language, a low level of motivation. Analyzing motivation components, the authors suggest the following ways to increase motivation:

- the motivation for the ultimate goal - participating in exchange programs, getting an education in a foreign country, a future job; 
- the motivation for the means of learning a language - singing songs in class; implementing some techniques of the project technology; implementing the case technology; using electronic educational resources.

According to some researchers (Barinova, 2017; Mushkina, 2017), the effective means of increasing motivation for second foreign language learning are electronic educational resources, information and communication technologies for teaching foreign languages.

Thus, the review of domestic studies of schoolchildren motivation for second foreign language learning has shown that some attempts are being made in the domestic science to comprehend the existing problems; it is acknowledged that there is a need to expand a range of foreign languages to study at Russian schools and to develop foreign language teaching methods. However, there is inconsistency in the language education goals, ambiguity and an insufficient degree of development of methods and techniques of second foreign language teaching. These are usually teachers of Second Foreign Language who have to face and try to solve the problem of developing schoolchildren motivation for second foreign language learning. But there is no scientific research on the problem.

It should be noted that the problem of increasing motivation for second foreign language learning is being actively explored in European and American science and is well worked out since second foreign language teaching has been carried out at schools for a long time. On the one hand, the analysis of the foreign experience in second foreign language learning can become a basis for improving the teaching methods. On the other hand, the results of psychological and pedagogical research can make a reliable theoretical basis for developing the content and methods of teaching Second Foreign Language.

Thus, C.J. Ovando (2010) argues that the United States language ideology has changed in accordance with the historic events taking place. The essence of the change is that the country's response to linguistic diversity has been shaped by the political, social, and economic forces and not by any consistent ideology. He comes to the conclusion that linguistic diversity is going to grow in the globalized world community, and this trend should be reflected in school language education.

The same idea was developed in the paper by J.A. Freire and V.E. Valdez (2017). The authors are supporters of culturally relevant pedagogy and suggest employing critical socio-cultural theory in foreign language teaching. The authors are convinced that increasing motivation for second foreign language learning is associated with overcoming such barriers as lack of time, lack of culturally relevant materials, lack of knowledge; they also believe that social justice topics are inappropriate for young children.

Fundamental studies in the field of language, neurology, and language disorders were conducted by J. Jonak (2015). The author believes that language acquisition, and second language acquisition, in particular, encompasses such factors as age, environment, and the correlation between fluency in one language and competence in the second one. Consequently, the study and application of language acquisition theory necessarily incorporate a comprehensive and evolving spectrum of language and language-related neurology research. It is important to move away from a wellmeaning but kaleidoscopic view of language acquisition toward a more comprehensive model of language acquisition by children aged 5 to 18 .

Since the beginning of the 21 st century, in foreign psycho-pedagogical studies, there has been an increased interest in the strategies that students employ while learning a foreign language, including the second one. This interest is based on the relationship between the strategies employed and the success in learning the second language by a schoolchild. Due to this fact, the following studies are relevant.

XLinguae, Volume 11 Issue 1, January 2018, ISSN 1337-8384, eISSN 2453-711X 
M. Ernesto (2006) makes a conclusion that there should be more theoretical rigor to understand the essence of an educational strategy, which should be differentiated from skills, processes, and styles. The author does not offer a comprehensive definition of the strategy but proposes features essential to describing a strategy. According to Ernesto, this approach helps both the teacher and the student in the process of foreign language acquisition.

A.I. Schwartz, L. Mendoza and B. Meyer (2017) studied the efficacy of learning a text structure strategy for improving reading comprehension and recall for the second language (L2) learners, as well as the tested transfer of the strategy to the native language (L1). At pre-test and post-test participants read and recalled two texts, one in Spanish and the other in English underlining areas of text that they deemed important. After completing strategy instruction, participants made significant gains in their ability to recall information from the text in both English and Spanish, despite the fact that all instructions and practice were in English only.

From our point of view, there are quite a lot of scientists who have found interesting methodological approaches to foreign language teaching and instruction. For example, M.H. Ko (2012) developed a glossing technique used to aid reading comprehension and vocabulary learning. M. Jalilvand (2014) studied reading comprehension in asymmetric and symmetric groups of students. E. Rod and Y. Sheen (2006) explored the social and socio-cognitive aspects of foreign language learning.

In conclusion, the analysis of foreign research on the development of schoolchildren motivation for foreign language learning has shown that there is a relationship between motivation for learning and the socio-cultural situation of the student's development. Involvement of students in foreign language communication at every day, social, and cultural levels activates the development of motivation for learning. To learn a foreign language, including the second one, becomes a vital necessity for some schoolchildren. At the same time, such things as scientific conferences, publication of journals devoted to bilingualism, scientific communities studying bilingualism problems suggest acute scientific interest in the problem.

\section{Materials and Methods \\ 1. Research methods}

To test the research hypothesis, various complementary methods were used:

- the theoretical method - analysis of the research on the problem carried out by teachers and psychologists; analysis of methodological and educational literature; theoretical analysis of the main conditions of the suggested methodology on the basis of which the research hypothesis was put forward; theoretical justification of the system of work with students to develop motivation for second foreign language learning;

- the empirical method - participant observation, ascertainment and formation pedagogical experiment, questioning, testing, a method of expert estimations, analysis of the results of the experimental work.

\section{Stages of the research}

The research was carried out at secondary school № 25 in Syktyvkar, the Komi Republic, and at some schools of Kirov, the Kirov region. 138 ninth-graders were the participants of the research.

The research consisted of three stages:

At the first stage, the process of preparation for Second Foreign Language introduction at Kirov region schools was monitored; we studied the experience of foreign language teachers who teach two or more languages; questioning of students studying German as a second foreign language was carried out; levels of motivation were established; evaluation of the research topic was carried out at the initial stage of the ascertainment experiment. 
At the second stage, the theoretical concept of the research was corrected and defined more precisely; methods for developing motivation for second foreign language learning were developed and tested; "anti-motives" and ways to overcome them were identified; a teaching experiment was conducted at schools of Kirov and the Kirov region and in Syktyvkar of the Komi Republic.

At the third stage, we carried out the analysis, integration, and systematization of the obtained data; the research documents were drawn up; the research topic was discussed in publications and the author's reports at scientific conferences.

At present, the research is being carried out within the framework of scientific supervision of the Master's thesis on the topic "Managing Second Foreign Language Project at a Secondary School" written by Malysheva, a student of the Vyatka State University.

\section{Results and Discussion}

\section{Information about the experimental research work}

Diagnostic assessment of learning motivation of high school students was done according to the method by Lukyanova and Kalinina (Gusev, 2011), modified relative to the motivation for learning German as a second foreign language. The participants were asked to make 18 statements, incorporated in 3 motivation blocks (personal meaning of learning, ability to set targets, other motives). Each suggested answer in the blocks has a certain number of points, depending on which motive manifests itself in this answer: the external motive -0 points; the play motive -1 point; the motive for getting a mark -2 points; the positioning motive -3 points; the social motive -4 points; the learning motive -5 points.

The diagnostic data are processed in accordance with Table 1.

Table 1: Levels of learning motivation according to Lukyanova and Kalinina (Gusev, 2011)

\begin{tabular}{|c|c|c|c|c|}
\hline \multirow{2}{*}{$\begin{array}{c}\text { Motivatio } \\
\text { n levels }\end{array}$} & \multicolumn{3}{|c|}{ Blocks } & \multirow{2}{*}{$\begin{array}{l}\text { Total points of } \\
\text { the resulting } \\
\text { motivation } \\
\text { level }\end{array}$} \\
\hline & 1 & 2 & 3 & \\
\hline I & $26-29$ & $24-28$ & $24-28$ & $72-85$ \\
\hline II & $21-25$ & $18-23$ & $18-23$ & $55-71$ \\
\hline III & $18-20$ & $12-17$ & $14-17$ & $42-54$ \\
\hline IV & $15-17$ & $8-11$ & $9-13$ & $30-41$ \\
\hline V & до 14 & До 7 & до 8 & до 29 \\
\hline
\end{tabular}

Thus, the following motivation levels can be described:

Level I - very high. Students consider learning the second foreign language as a personally significant activity. They are ready to take the initiative in setting personally-significant learning goals. They prefer creative tasks that allow expressing their ideas and feelings. The second foreign language for them is a tool for selfdevelopment and self-expression. Students consider learning the second foreign language as a way of realizing their own creative potential.

Level II - high. Learning the second foreign language, students aim at meeting the Federal State Education Standards. They realize that it is really important to 
successfully pass the USE in a foreign language. They are ready to overcome difficulties. Students consider studying the second foreign language as their responsibility.

Level III - normal (medium). Students follow all the instructions of the teacher, they are conscientious and responsible, and they are upset when they get unsatisfactory marks. They do all the homework assignments given by the teacher and actively participate in the classroom. They consider learning the second foreign language as a requirement.

Level IV - reduced. Students feel a situational interest in learning the second foreign language: they are attracted by entertaining tasks (sayings, poems, visual information) and play tasks. They lose interest when they have to master new vocabulary and grammar rules. Students consider studying the second foreign language as pleasure.

Level V - low. Students feel a serious dissonance between being aware of the importance of knowing a foreign language and making enough effort to master it. Students consider studying the second foreign language as a duty.

\section{The results of the experimental research}

The research was carried out at secondary school No. 25 of Syktyvkar, the Komi Republic, by Irina Malysheva, a student of the Institute of Foreign Languages of the Syktyvkar State University named after Pitirim Sorokin. Some schools of the Kirov region participated in the experiment too. These are school No. 1 of Kotelnich and the Slobodskoy gymnasium which are regional innovation sites of the Vyatka State University (supervised by Olga G. Selivanova, Ph.D., associate professor). During the experiment, the teachers carried out a humanitarian assessment of foreign language lessons to reveal the innovative experience in developing motivation for foreign language learning; they also conducted interviews with students who demonstrated good results in foreign language learning; parents meetings were also conducted to reveal parents' influence on the motivation for foreign language learning.

The task of the ascertainment stage of the experiment was as follows: to determine the dominant motive of schoolchildren in learning German as the second foreign language.

At this stage, 138 ninth-graders studying German as the second foreign language underwent a diagnostic assessment. English was their first foreign language. Experimental and control groups were formed on the basis of the results of the initial diagnostic assessment. The results are given in Table 2.

Table 2: The results of the initial diagnostic assessment of levels of motivation for second foreign language learning in the experimental and control groups

\begin{tabular}{|c|c|c|}
\hline \multirow{2}{*}{ Motivation Levels } & \multicolumn{2}{|c|}{ \% respondents } \\
\cline { 2 - 3 } & Experimental Group & Control Group \\
\hline I & 8 & 9 \\
\hline II & 10 & 10 \\
\hline III & 23 & 25 \\
\hline IV & 20 & 25 \\
\hline V & 39 & 31 \\
\hline
\end{tabular}

In order to identify the qualitative characteristics of motivation for learning German as the second foreign language, a series of group talks, panel discussions, round-table discussions were organized. Such pedagogical technologies as that of critical thinking, debate technology, and some others were used in discussions. As a result, it was found out that $70 \%$ of schoolchildren like German lessons, however, $20 \%$ would prefer to attend a different lesson, because they experience difficulties in learning the second 
foreign language. $30 \%$ of students mentioned a great role of parents in shaping their attitude to language learning: a positive attitude of parents is passed on to students. The qualitative analysis confirmed the conclusion that external and game motives prevail, followed by the motive for getting a mark and the positioning motive. The assessment figures for the educational motive and the social one were the lowest. We found out that even in this case there arise "anti-motives" which get accumulated so that students need support. Among the factors that can change the attitude to foreign language learning, the students named changing the content and employing other types of activities in class. Some students believed that language learning should be more practice-oriented. In their opinion, extracurricular activities in a foreign language offer such opportunities. These data show the necessity to develop and apply a system of tasks and assignments to improve and maintain schoolchildren learning motivation at German lessons.

The task of the formation stage was to test the system of tasks and assignments devised by the author. They were aimed at developing motivation of students for learning German as the second foreign language. Experimental training was conducted for 9th-grade students studying German as a second foreign language in October 2016 - February 2017.

We developed a system of tasks and assignments to improve schoolchildren motivation for second foreign language learning taking into consideration their existing motivation level which should determine the tasks, content, and types of the teacher's work. The set of tasks and assignments is devised for individual or group work, which gets schoolchildren of the same motivation level together in class and when they participate in extracurricular activities.

The suggested approach is given below as a table (Table 3).

Table 3: The system of assignments to develop schoolchildren motivation for second foreign language learning

\begin{tabular}{|c|c|c|}
\hline $\begin{array}{l}\text { Motivation } \\
\text { levels }\end{array}$ & Tasks & Content and teaching techniques \\
\hline $\mathrm{I}$ & $\begin{array}{l}\text { Supporting the } \\
\text { learning self- } \\
\text { fulfillment motive, } \\
\text { preventing a decrease } \\
\text { in motivation or } \\
\text { preventing "anti- } \\
\text { motives" to arise }\end{array}$ & $\begin{array}{l}\text { Organizing face-to-face or distant, verbal } \\
\text { or written communication with native } \\
\text { speakers. } \\
\text { Reading authentic German texts, } \\
\text { newspapers, and best classic German } \\
\text { literature. } \\
\text { Participation in competitions } \\
\text { Working with the teacher's site } \\
\text { Making use of electronic educational } \\
\text { resources }\end{array}$ \\
\hline II & $\begin{array}{lr}\begin{array}{l}\text { Supporting } \\
\text { motivation the } \\
\text { achieving the goal, } \\
\text { focusing } \\
\text { obligatory }\end{array} \\
\text { requirements }\end{array}$ & $\begin{array}{l}\text { Informing students of the requirements of } \\
\text { the Federal-State Education Standards for } \\
\text { each topic in the Second Foreign Language } \\
\text { syllabus } \\
\text { Giving students the right to choose the } \\
\text { level, content, and a way of performing } \\
\text { tasks }\end{array}$ \\
\hline III & $\begin{array}{l}\text { Supporting } \\
\text { motivation } \\
\text { achieving } \\
\text { success }\end{array}$ & $\begin{array}{l}\text { Giving tasks which have clearly stated } \\
\text { evaluation criteria for all kinds of language } \\
\text { activities: reading, writing, speaking, } \\
\text { listening. }\end{array}$ \\
\hline
\end{tabular}

XLinguae, Volume 11 Issue 1, January 2018, ISSN 1337-8384, eISSN 2453-711X 


\begin{tabular}{|c|l|l|}
\hline IV & $\begin{array}{l}\text { Supporting the desire } \\
\text { motivation }\end{array}$ & $\begin{array}{l}\text { Involving schoolchildren in play activities, } \\
\text { learning songs, proverbs and sayings, } \\
\text { poems } \\
\text { When giving a task, such words as "play," } \\
\text { "build," "imagine," "solve a riddle" should } \\
\text { be used. }\end{array}$ \\
\hline V & $\begin{array}{l}\text { Supporting the } \\
\text { success motivation }\end{array}$ & $\begin{array}{l}\text { Giving tasks of a reproductive nature } \\
\text { which have clear instructions how to do } \\
\text { them, following "here and now" principle }\end{array}$ \\
\hline
\end{tabular}

The aim of the control stage is to reveal changes in the development of schoolchildren motivation for second foreign language learning.

The control stage of the experiment took place in April 2017. The same method was used to carry out the final diagnostic assessment of motivation levels. The results are shown in Table 4.

Table 4: The results of the final diagnostic assessment of levels of motivation for second foreign language learning in the experimental and control groups

\begin{tabular}{|c|c|c|}
\hline \multirow{2}{*}{ Motivation levels } & \multicolumn{2}{|c|}{ \% respondents } \\
\cline { 2 - 3 } & Experimental Group & Control Group \\
\hline I & 16 & 10 \\
\hline II & 12 & 12 \\
\hline III & 26 & 22 \\
\hline IV & 20 & 22 \\
\hline V & 26 & 34 \\
\hline
\end{tabular}

Comparing the results of the initial and final diagnostic assessment one can see that there is an increase in schoolchildren motivation for learning German as the second foreign language at all levels.

The analysis of the qualitative characteristics of motivation has also shown positive changes. Many students see Foreign Language as one of their favorite subjects. Most students mention that they like the way the teacher teaches: "The teacher often praises me," "The teacher gives interesting explanations." Many students see the importance of a foreign language for future work, for entering a university; they admit its entertaining and useful nature. Strengthening of cognitive motives of ninth-graders is revealed by their choice of such statements as "The subject is entertaining," "It helps to develop cultural awareness," "It upgrades your knowledge about the world around." The results have shown a higher level of student motivation compared with a similar qualitative analysis conducted at the initial stage of the experiment.

\section{Conclusion}

The following results were achieved in the course of the research:

1) the scientific and methodological approach to developing schoolchildren motivation for second foreign language learning was justified; its essence consists in individual support, teacher's assistance and support of a student in accordance with the student's motivation level;

2) a set of assignments to organize individual and group work was devised, it was aimed at developing their motivation for second foreign language learning;

3 ) the organizational and pedagogical conditions necessary to develop schoolchildren motivation for second foreign language learning were identified:

1. The teacher should know the first foreign language (English) proficiency level of students. 
2. It is necessary to study quantitative and qualitative characteristics of motivation for learning German as the second foreign language;

3. It is necessary to take students' individual cognitive characteristics and educational needs in learning the second foreign language into consideration;

4. The teacher should be aware of the necessity to develop motivation of each schoolchild regardless of the motivation level.

The process of teaching the German language from the point of view of influencing students' motivation can be deemed as successful and effective if there is a significant increase in the number of students having a high or very high level of learning motivation and a significant reduction in the number of students with low learning motivation (due to transition from the low level to the medium or high ones). Positive dynamics in the development of learning motivation can be regarded as evidence of highly effective educational process in a certain educational organization. The reverse trend (growing number of students who have a low motivation level or no development or significant differences when moving from stage to stage) suggests that there are significant problems in the work of a Foreign Language teacher in terms of solving pedagogical problems.

The paper can be of practical value for teachers of any foreign language, as this approach does not take into consideration the characteristic aspects of the first or second foreign languages studied by students.

\section{Acknowledgement}

The work is performed according to the Russian Government Program of Competitive Growth of Kazan Federal University.

\section{Bibliographic references}

AUSUBEL, D.P. - ROBINSON, F.G. 1969. School learning: An introduction to educational psychology. New York: Holt. Rinehart \& Winston. ISBN 9780030767050 .

AUSUBEL, D.P. 1963. The psychology of meaningful verbal learning. New York: Grune \& Stratton.

AUSUBEL, D.P. 1968. Educational Psychology: A Cognitive View. New York and Toronto: Holt, Rinehart \& Winston.

Author's subject site of the German language teacher.M.N. Mushkina. Retrieved September 30, 2017, Available online: http://166deutsch.ucoz.net

BARINOVA, S.E. 2017. Innovative technologies in teaching foreign languages: the principles of constructing an optional course "Second Foreign Language in a Comprehensive School" Retrieved October 3, 2017, Available online: http://festival.1september.ru/authors/210-482-920/

CHERKASOVA, A.A. 2017. The problems of teaching French as a second foreign language and ways to eliminate them. Science, education, society: trends and development prospects: Materials of V International Scientific-practical Conference. Cheboksary, Russia. pp. 153-155. ISBN 978-5-9909609-7-8.

DUBROVIN, M.I. 2012. Motivation for teaching a foreign language and teaching materials. In: Foreign languages in school, n. 5, pp. 25-28. ISSN 0130-6073.

ERNESTO, M. 2006. Strategies for language learning and for language use: Revising the theoretical framework. In: The Modern Language Journal (Blackwell), n. 90.3, pp. 320-337. ISSN 0026-7902.

FREIRE, J.A. - VALDEZ, V.E. 2017. Dual language teachers' stated barriers to implementation of culturally relevant pedagogy. In: Bilingual Research Journal, vol. 40, n.1, pp. 55-69. ISSN 1523-5882.

GALSKOVA, N.D. 2014. Modern methods of teaching foreign languages. Moscow: Enlightenment. ISBN 5894152909.

XLinguae, Volume 11 Issue 1, January 2018, ISSN 1337-8384, eISSN 2453-711X 
GOTLIB, R.A. 2009. Social demand for knowledge of a foreign language. In: Sociological research, n. 2, pp.122-127. ISSN 0132-1625.

GUSEV, A.V. 2011. The connection between learning and motivation for studying a foreign language.

RGPU. Available online: http://www.rspu.edu.ru/university/publish/journal/gusev.motivation1.htm

JALILVAND, M. 2014. The effect of peer and teacher scaffolding on the reading comprehension of EFL learners in asymmetrical and symmetrical groups. In: Journal of Teaching Language Skills, vol. 5, n. 4, pp. 1-17. ISSN 2008-8189.

JONAK, J. 2015. Bilingual Language Development and language impairment in children. In: Acta neuropsychological, vol. 13, n.1, pp. 63-79. ISSN 1730-7503, 2084-4298.

KO, M.H. 2012. Glossing and second language vocabulary learning. In: Tesol Quarterly, vol. 46, n. 1, pp. 56-79. ISSN 1545-7249.

MUSHKINA, M.N. 2017. Ways to solve the problems of teaching a second foreign language. Actual problems of modern pedagogy: materials of the $\mathrm{X}$ International Scientific Conference. Samara, Russia. pp. 89-91. ISBN 978-5-9905791-5-6.

Order of the Ministry of Education and Science of the Russian Federation of December 31, 2015 No. 1577 "On Amendments to the Federal State Educational Standard of Basic General Education, approved by Order of the Ministry of Education and Science of the Russian Federation of December 17, 2010 No. 1897" Retrieved October 4, 2017, Available online: https://www.google.ru/search

OVANDO, C.J. 2003. Bilingual Education in the United States: Historical Development and Current Issues. In: Bilingual Research Journal, vol. 27, n. 1, pp. 124. ISSN 1523-5882.

PASSOV, E.I. - KUZOVLEV, V.P. - KOROSTELEV, V.S. 2010. The purpose of teaching a foreign language at the present stage of society development. In: Foreign languages in school, n. 6, pp. 21-23. ISSN 0130-6073

ROD, E. - SHEEN, Y. 2006. Reexamining the role of recasts in second language acquisition. In: Studies in Second Language Acquisition (Cambridge University Press), vol. 28, n. 4, pp. 575-600. ISSN 02722631.

ROGOVA, G.V. - NIKITENKO, Z.N. 2009. On some ways of increasing the motivation for studying foreign languages among schoolchildren in V-VII grades. In: Foreign languages in school, n. 6, pp. 22-25. ISSN 0130-6073.

SAFONOVA, V.V. 2012. Cultural and linguistic expansion and its manifestation in language policy and education. In: Foreign languages in school, n. 3, pp. 23-26. ISSN 0130-6073.

SCHWARTZ, A.I. - MENDOZA, L. - MEYER, B. 2017. The impact of text structure reading strategy instruction in a second language: benefits across languages. In: The Language Learning Journal, vol. 45, n. 3, pp. 263-281. ISSN 09571736.

SYSOEVA, P.V. 2011. Language and culture: in search of a new direction in the teaching of the studied language. In: Foreign languages in school, n. 4, pp. 11-13. ISSN 0130-6073.

VARTANOV, A.V. 2003. From teaching languages to teaching foreign languages and cultures. In: Foreign languages in school, n. 2, pp. 55-57. ISSN 0130-6073.

VEDISHENKOVA, M.V. - GULYAEVA, V.S. 2016. Background and prospects of schoolchildren's polylingual education in the context of new federal state educational standards. In: International Journal of Environmental and Science Education, vol. 11, n. 8, pp. 1889-1900. ISSN 1306-3065.

YURCHENKOVA, G.D. 2010. Motives and "anti-motives" in learning a foreign language. In: Foreign languages in school, n. 4, pp. 29-31. ISSN 0130-6073.

ZIMNYAYA, I.A. 2014. Psychology and methodology of teaching a foreign language in school. Moscow: Enlightenment. ISBN 5-09-001716-6. 
Words: 5987

Characters: 38044 (21,14 standard pages)

Assoc. Professor Olga G. Selivanova, PhD

Pedagogical Institute,

Vyatka State University,

36 Moskovskaya Str.

610000 Kirov

Russia

selivanog@mail.ru

Assoc. Prof. Chulpan R. Gromova, PhD

Institute of Psychology and Education

Kazan (Volga region) Federal University

18 Kremlyovskaya Str.

420008 Kazan

Russia

gromovajob@rambler.ru

Prof. Nikolay A. Mashkin, Dr.

Department of State-Legal and Criminal Law Disciplines

Plekhanov Russian University of Economics

Moscow, Russia

36 Stremyannyi Pereulok Str.

115093 Moscow

Russia

mashkin.n.a@mail.ru 